\title{
Fleet mix in container shipping operations
}

\author{
Y.H. Venus Lun*
}

Department of Logistics and Maritime Studies, The Hong Kong Polytechnic University, 11 Yuk Choi Road, Hung Hom, Kowloon, Hong Kong

Fax: 852-23302704

E-mail: lgtvlun@polyu.edu.hk

*Corresponding author

\section{Michael Browne}

Transpot Studies Department,

University of Westminster,

35 Marylebone Road, London NW1 5 LS, UK

E-mail: M.Browne@westminster.ac.uk

\begin{abstract}
In the context of container shipping, carrying capacity can be one of the resources for better firm performance. Shipping is one of the most capital intensive industries as carriers need to acquire ships to offer shipping services to their customers. Although it seems intuitive for carriers to deploy mega ships to achieve cost efficiency, it requires a balance between shipping services and ship size in determining their fleet mix. This study provides empirical evidence to examine the issue of scale operations and service scope in the container shipping industry. Our findings suggest that carrying capacity of shipping firms positively affect their firm performance. As fleet mix is concerned with the number of ships and the size of ships, we used path analysis to examine the impact of number of ships and average ship size on firm performance. In comparing the magnitude of the effect, the number of ships has stronger impact on firm performance than ship size. In this study, we also introduce a 'SCOPE' framework which consists of the dimensions concerning service frequency, customer value, optimal vessel size, ports of call and extensive market coverage, which is useful for shipping managers to determine their fleet mix in liner shipping services.
\end{abstract}

Keywords: fleet mix; container transport; shipping operations; shipping capacity; service scope.

Reference to this paper should be made as follows: Lun, Y.H.V. and Browne, M. (2009) 'Fleet mix in container shipping operations', Int. J. Shipping and Transport Logistics, Vol. 1, No. 2, pp.103-118.

Biographical notes: Venus Lun (DBA, Curtin University of Technology) is Lecturer at The Hong Kong Polytechnic University. Her research interests include shipping logistics, port management, container transport operations and liner shipping management. She is the Author of a number of books on shipping and logistics, including 'Container Transport Management', 'Adoption of Electronic Commerce by Logistics Service Providers' and 'Shipping and Transport Logistics'. She has published numerous articles in academic journals such as International Journal of Production Economics, International Journal of Shipping and Transport Logistics, Transport Reviews and Transportation Journal. Before entering academia, she had worked in the liner shipping industry for over ten years, occupying managerial positions in top shipping firms such as Maersk, Hapag-Lloyd and CMA CGM.

Copyright (C) 2009 Inderscience Enterprises Ltd. 
Michael Browne, Professor of Logistics, is responsible for directing freight and logistics research at the University of Westminster. His research interests include developments in global freight transport and logistics, innovative distribution strategies for European cities, the energy use implications of global sourcing and potential energy savings from city logistics strategies. He has worked on studies for the European Commission, Department for Transport, the Research Councils and commercial organisations. He represents the University on many external committees and boards and chairs the Central London Partnership FQP (Freight Quality Partnership).

\section{Introduction}

In a globalising market place with increased global sourcing activities, dwindling transport cost and widely diffused production sites, the volume of international trade has grown dramatically (Robinson, 2002). Shippers increasingly expect their carriers and logistics service providers to provide more rapid and reliable delivery services with an aim to minimise their cost of warehousing, inventory holding and the related activities such as production and distribution. Facing these customer expectations, carriers offer a wider variety of services and more cost-effective shipping options to meet their customer needs. While container shipping is a major transport mode of international trade today, containerisation in the 1970s brought a revolution in sea transport operations. The 4Cs forces, namely containerisation, concentration, collaboration and competition, can be used to describe the business operating environment of container shipping (Lun et al., 2009).

\subsection{Containerisation}

Malcolm Mclean commenced the container shipping history with the voyage of the Ideal X, a modified 20-year old tanker, in April 1956. From this beginning, one of the most far-reaching and fundamental history of container transport took shape and was then extended to major shipping routes in the world. Since the introduction of containers, container transport has been growing (Song et al., 2005). Containerisation plays a significant role in facilitating trade and supporting economic development of emerging countries as container ships replace the less efficient traditional vessels and enables global production and distribution, which reduces transaction costs remarkably. Containerisation has reduced global transportation costs drastically with the average cost of maritime shipping as a percentage of the total retail cost of manufactured goods fell $80 \%$ in the past 20 years (Kwan and Knutsen, 2006). Container shipping has transformed the technologies and methods of unitised cargo movements. While ships, trains, trucks, terminals and freight stations have changed in their designs to handle containers, transport control systems and freight-documentation systems have been integrated to facilitate flows of containers across different transport modes. As such, all modes and systems of freight transport are involved in the container revolution (Fleming, 2002; 2003). 


\subsection{Concentration}

Container vessels are expensive and buying of new ships involves huge financial risk because of the lead time between ordering and the deployment of a new vessel. Additions to shipping capacity must be tailored to infrastructure constraints such as the channel width and depth of ports, as well as the loading and unloading facilities at seaports (Fusillo, 2004). Withdrawing capacity during recession is also costly. Nevertheless, the container shipping business has entered into a phase where carriers reap economies of scale in ship size (Cullinane and Khanna, 2000). On the other hand, carriers need to have sufficient cargo volume to fill their ships. Shipping lines need to offer enhanced services such as increasing the number of ports of call and higher sailing frequency to improve global market coverage. Although such increase of geographical coverage raises operating costs, the improved services attract sufficient cargo volume to allow shipping lines to enjoy scale economies in their operations, reducing the cost per unit of container handling, as well as intermodal and feeder service (Midoro and Pitto, 2000). Concentration of container shipping services contributes to economies of scale and generates revenue. The concept of cost economy leads shipping firms to expand by enlarging their fleets and allocating more ships to serve worldwide markets (Slack et al., 2002). Concentration in recent years is a result of increased carrying capacity by the largest container shipping operators. The concentration ratio (CR) is an indicator of the relative size of firms in relation to the industry as a whole. For example, a CR4 calculates the market share of the leading four firms. As shown in Table 1, the big four container transport operators increased their carrying capacity to four million TEU (i.e., $38.3 \%$ of the world total container carrying capacity) in 2007. As the container shipping market is dominated by the top shipping lines $(\mathrm{CR} 4=0.383)$, there is a lack of new entrants to the list of the top carriers (UNCTAD, 2004).

Table 1 Evolution of container shipping capacity from 2000 to 2007

\begin{tabular}{lcccc}
\hline $\begin{array}{l}\text { Container shipping } \\
\text { carriers }\end{array}$ & $\begin{array}{c}\text { January 2000 } \\
\text { capacity (in TEU) }\end{array}$ & $\begin{array}{c}\text { January 2007 } \\
\text { capacity (in TEU) }\end{array}$ & $\begin{array}{c}\text { Market } \\
\text { share (2007) }\end{array}$ & Rank \\
\hline Maersk & 620,324 & $1,759,619$ & $16.8 \%$ & 1 \\
MSC & 224,620 & $1,026.251$ & $9.8 \%$ & 2 \\
CMA CGM & 122,848 & 685,054 & $6.5 \%$ & 3 \\
Evergreen & 317,292 & 547,576 & $5.2 \%$ & 4 \\
Hapag-Lloyd & 102,769 & 458,161 & $4.4 \%$ & 5 \\
China shipping & 86,335 & 399,821 & $3.8 \%$ & 6 \\
COSCO & 198,841 & 387,690 & $3.7 \%$ & 7 \\
Hanjin senator & 244,636 & 348,235 & $3.3 \%$ & 8 \\
APL & 207,992 & 339,036 & $3.2 \%$ & 9 \\
NYK & 166,206 & 329,324 & $3.1 \%$ & 10 \\
MOL & 136,075 & 281,807 & $2.7 \%$ & 11 \\
OOCL & 101,044 & 281,113 & $2.7 \%$ & 12 \\
K Line & 112,884 & 275,634 & $2.6 \%$ & 13 \\
CSAV & 69,745 & 250,452 & $2.4 \%$ & 14 \\
Zim & 132,618 & 241,951 & $2.3 \%$ & 15 \\
\hline
\end{tabular}

Source: AXS-Alphaliner 
Table 1 Evolution of container shipping capacity from 2000 to 2007 (continued)

\begin{tabular}{lcccc}
\hline $\begin{array}{l}\text { Container shipping } \\
\text { carriers }\end{array}$ & $\begin{array}{c}\text { January 2000 } \\
\text { capacity (in TEU) }\end{array}$ & $\begin{array}{c}\text { January 2007 } \\
\text { capacity (in TEU) }\end{array}$ & $\begin{array}{c}\text { Market } \\
\text { share (2007) }\end{array}$ & Rank \\
\hline Yang Ming & 93,348 & 240,305 & $2.3 \%$ & 16 \\
Hamburg-Sud & 68,119 & 204,960 & $2.0 \%$ & 17 \\
Hyundai & 102,314 & 164,700 & $1.6 \%$ & 18 \\
PIL & 60,505 & 145,500 & $1.4 \%$ & 19 \\
Wan Hai & 63,525 & 115,009 & $1.1 \%$ & 20 \\
UASC & 74,989 & 86,608 & $0.8 \%$ & 21 \\
IRIS & 19,920 & 59,900 & $0.6 \%$ & 22 \\
MISC & 41,738 & 58,013 & $0.6 \%$ & 23 \\
Girmaldi & 35,283 & 56,668 & $0.5 \%$ & 24 \\
RCL & 26,355 & 46,466 & $0.4 \%$ & 25 \\
Others & $1,306,388$ & $1,677,643$ & $16 \%$ & - \\
Total & $5,150,000$ & $10,467,496$ & $100 \%$ & - \\
\hline
\end{tabular}

Source: AXS-Alphaliner

\subsection{Collaboration}

The shipping slot is a highly perishable inventory in container shipping operations. Once ships depart from the loading ports, no revenue will be generated from the unused slots as they cannot be stored as an inventory for later sales like physical goods (Ting and Tzeng, 2004). However, new building orders for larger containerships have grown exponentially. This is because of increasing collaboration among shipping firms that encourages investment in larger container ships (Cullinane and Khanna, 2000). Vessel sharing agreements are a common form of collaboration for shipping firms to share slot to reduce risk and achieve scale economies through the deployment of large container ships. Due to globalisation, more countries are competing in the global market, which has resulted in an increase in competition in international trade (Song, 2003). To meet such market needs, rationalisation, as a set of processes that are structured to deliver quality services to satisfy customers, has become prevalent in the shipping industry. The collaboration amongst shipping firms aims to consolidate carriers' resources in the market to maximising market shares and minimising running costs. Shipping lines develop global networks to collaborate with counterparts to facilitate movement of cargoes around the global market. On the other hand, globalisation of container lines has resulted in greater market power as international shipping lines have more choices in port calling patterns. The network members can also negotiate collectively with container terminal operators for favourable service charges and conditions. Hence, collaboration can be an excellent tool for container shipping firms to achieve mutually beneficial gains.

\subsection{Competition}

When a mega carrier announces a decision to build (or order) larger ships, its competitors are likely to act as followers as larger ships operate at lower per unit costs if the shipping capacity is fully utilised. However, carriers have to engage in a degree of service rationalisation to ensure that shipping spaces can be completely filled. To compete, 
container shipping firms increasingly focuses on the needs of customers. As the competition intensifies, shipping lines seek to own or control container terminals with an aim to eliminate the middleman. If a shipper needed help getting containers out of a terminal in the shortest possible time, the carrier should be able to provide such help responsively instead of relying on a third party terminal operator. On the other hand, competition leads to a sacrifice in the carrier's operating flexibility in meeting shippers' need for speedy and reliable container services (Fleming, 2002; 2003). In addition to offering low cost services, container shipping firms increase service options and quicker responses to their customers to help them to cope with the dynamic business environment. This can help container shipping firms to meet the continuously rising customer expectations on cost savings and improvement of efficiency from shipping services.

These 4C forces, i.e., containerisation, concentration, collaboration and competition, provide an overview of the characteristics of container shipping operation environment. The world fleet has experienced continuous growth in all the categories of the fully containerised ships. As shown in Table 1, the total capacity of containership fleet in 2007 was increased to $10,467,497$ TEUs (as shown in Table 1).

In this globalised age, the growth in seaborne container trade will continue with increased international business collaboration. With the growth in demand for container transport, the container shipping capacity is expected to increase as seaborne trade activities rely on the capacity of the world's fleet. Carriers can adjust their capacity by deploying ships of different sizes. Managers often perceive growth and large scale operations as desirable goals for shipping firms. Growth leads to scale operations and increase operational capacity often associated with prestige and the ability to withstand difficulties in a dynamic business environment. In this study, we provide empirical evidence to examine the issues of scale operations and service scope in the container shipping industry. The performance implications will also be discussed.

\section{Liner shipping services}

Liner shipping is committed to a regular publicised schedule of shipping service between ports. A function of liner shipping is to satisfy the shipping demand for regular freight transport. Liner ships operate for international seaborne trade with cargo consolidated from a large number of consignments from different shippers. A key objective for liner shipping operations is to utilise their fleets optimally. Operating a large ship involves huge capital investment and high daily operating costs. Shipping companies can gain efficiency from improving fleet utilisation through ship routing, which is referred to the assignment of sequences of ports to be visited by ships. The factors needed to take into account for shipping firms to plan a liner shipping service include shipping service scope and fleet mix.

An important factor to consider when planning a liner service route is to decide service scope and type of shipping routes. Traditionally, shipping lines operate three general types of shipping routes, namely port to port, pendulum and round the world shipping routes: 
- Port to port involves regular shipping service between two ports, often moving back and forth, but very likely the shipping route is unidirectional. This route pattern has the disadvantage of limited connectivity.

- Pendulum involves a regular itinerary between sequences of ports, often serviced by geographical proximity. A cluster of ports along one seaboard are serviced and then an ocean is crossed. This process is repeated on a regular basis.

- Round the world involves serving continuously a sequence of ports, often in both directions, so that the sequence of ship visits enables a round trip around the world. A limited number of ports per continent are serviced. This type of maritime route planning is mainly used for container shipping.

With the growing complexity in liner shipping services, a hierarchical set of shipping networks has emerged (Robinson, 1998). High-order shipping service networks will have fewer ports of call and bigger vessels. The shipping networks are operated by large vessels based on scheduling vessels back and forth between two major continents and supported by a hub-and-spoke system (Gilman, 1999). In a hub-and-spoke system of containerised seaborne trade, a cargo is first delivered to a primary hub port, then transported to its final destination by feeder services. Similarly, exports are collected in a primary hub then transported to final destinations. While these primary ports are generally well equipped to facilitate a quick turnaround time of vessels, there are usually two primary characteristics that set them apart from other ports. Firstly, the primary hub tends to be geographically central to a region, sometimes with a hinterland to attract a considerable amount of cargo that would in any case flow through that port. The second characteristic is that the hub port can accommodate larger vessels than other ports in the region.

There is a trend in the shipping industry to change from direct call to the ports or hub-and-spoke services. Hubs, because of their direct connection to many spoke cities, are considered highly accessible places to consolidate cargoes. Hubs allow the construction of indirect linkages between origins and destinations, which can benefit operating cost, service provision and market position. A hub port serves as a trans-shipment place where feeder shipping routes are connected with one another and trunk routes for ocean-going voyages. The size and level of integration of a port to its hinterland determine the stability of its trans-shipment activities. A port is linked with the dynamics of territories, notably their economic functions (Rodrigue and Comtois, 1997). Recently, shipping lines have established connections with ports in order to make their trans-shipment operations most efficient and effective. As shipping lines deploy larger ships on main trade routes, it may not be economically sound to use a direct call approach.

Major carriers choose to use trans-shipment hubs. Trans-shipment occurs where export cargo is taken by feeder vessels from a feeder port to a hub port, usually on the same continent, for onward shipment to other vessels, to a third port usually on another continent. Import cargo follows this reverse process. This type of trans-shipment can be controlled by either the shipping line or the shipper. Line trans-shipment arises from coordinated schedules of mainline, while feeder vessels controlled by the shipping line. Shipper trans-shipment is opportunistic - it often exploits the services of different lines or modes with an aim to reduce transit time and/or costs. Another form of trans-shipment is relay, which is wholly controlled by the individual shipping lines, consortia or 
alliances concerned. This involves cargo carried on one main line vessel relayed to another one at a hub port. This relay traffic is sensitive to port costs and operations efficiency in cargo handling. With the increased significance of pendulum services and trans-shipment networks, most liner services on the main shipping routes are of the line-bundling type. According to Notteboom (2006), a line bundling loop is defined 'as a set of $x$ roundtrips of $y$ vessels each with a similar calling pattern in terms of the order of port calls and time intervals between two consecutive port calls'. By the overlay of these roundtrips, shipping firms can offer a desired calling frequency to their customers.

Fleet mix is makeup of the number of ships and the sizes of ships to deploy. Carriers normally offer at least a weekly service to the market. Liner shipping firms need to consider a trade-off between shipping service frequency and ship size. Deploying larger vessels will allow operators to benefit from scale economies, but potentially reduce the shipping service frequency. The optimal ship size therefore depends on cargo availability and the requirement for transit time. As economies of vessel size are more significant for long haul, bigger vessels are often deployed for deep sea trades. Decisions on fleet mix (i.e., the number and size of ships to deploy) are often made jointly with partners in a carrier cooperative scheme known as an alliance. Alliances through strategies such as individual service network integration, vessel sharing, slot chartering, slot exchange, joint ownership and utilisation of equipment and terminals are set up to deliver comprehensive liner shipping services to the market. For example, the PRX liner service takes a total transit time for a round trip voyage in 35 days. Considering that the cargo volume of Trans-Pacific trades is large, the alliance (CMA CGM and MSC) deploys five vessels of 8,100 TEU each to run this Trans-Pacific loop to offer a fixed day weekly sailing service. The schedule of this PRX service is shown in Table 2.

Table 2 Schedule for PRX service

\begin{tabular}{|c|c|c|c|c|c|c|}
\hline $\begin{array}{l}\text { Vessel } \\
\text { name }\end{array}$ & $\begin{array}{c}C M A \\
C G M \\
V I V A L D I\end{array}$ & $\begin{array}{c}M S C \\
T E X A S\end{array}$ & $\begin{array}{c}\text { PACIFIC } \\
\text { LINK }\end{array}$ & $\begin{array}{c}C M A C G M \\
H U G O\end{array}$ & MSC RITA & $\begin{array}{c}C M A \\
C G M \\
\text { VIVALDI }\end{array}$ \\
\hline $\begin{array}{l}\text { Eastbound } \\
\text { voyage }\end{array}$ & $T X 247 E$ & $T X 249 E$ & $T X 251 E$ & $T X 253 E$ & $T X 255 E$ & $T X 257 E$ \\
\hline Xiamen & $\begin{array}{c}\text { Sun, } \\
\text { 11-Jun-06 }\end{array}$ & $\begin{array}{c}\text { Sun, } \\
\text { 18-Jun-06 }\end{array}$ & $\underset{\text { Sun, }}{\text { Sun-06 }}$ & $\begin{array}{c}\text { Sun, } \\
\text { 02-Jul-06 }\end{array}$ & $\begin{array}{c}\text { Sun, } \\
\text { 09-Jul-06 }\end{array}$ & $\begin{array}{c}\text { Sun, } \\
\text { 16-Jul-06 }\end{array}$ \\
\hline Chiwan & $\begin{array}{c}\text { Mon, } \\
\text { 12-Jun-06 }\end{array}$ & $\begin{array}{c}\text { Mon, } \\
\text { 19-Jun-06 }\end{array}$ & $\begin{array}{c}\text { Tue, } \\
\text { 27-Jun-06 }\end{array}$ & $\begin{array}{c}\text { Tue, } \\
\text { 04-Jul-06 }\end{array}$ & $\begin{array}{c}\text { Tue, } \\
\text { 11-Jul-06 }\end{array}$ & $\begin{array}{c}\text { Mon, } \\
\text { 17-Jul-06 }\end{array}$ \\
\hline Hong Kong & $\begin{array}{c}\text { Tue, } \\
\text { 13-Jun-06 }\end{array}$ & $\begin{array}{c}\text { Tue, } \\
\text { 20-Jun-06 }\end{array}$ & $\begin{array}{c}\text { Wed, } \\
\text { 28-Jun-06 }\end{array}$ & $\begin{array}{c}\text { Wed, } \\
\text { 05-Jul-06 }\end{array}$ & $\begin{array}{c}\text { Wed, } \\
\text { 12-Jul-06 }\end{array}$ & $\begin{array}{c}\text { Mon, } \\
\text { 17-Jul-06 }\end{array}$ \\
\hline Yantian & $\begin{array}{c}\text { Wed, } \\
\text { 14-Jun-06 }\end{array}$ & $\begin{array}{c}\text { Wed, } \\
\text { 21-Jun-06 }\end{array}$ & $\begin{array}{c}\text { Thu, } \\
\text { 29-Jun-06 }\end{array}$ & $\begin{array}{c}\text { Thu, } \\
\text { 06-Jul-06 }\end{array}$ & $\begin{array}{c}\text { Wed, } \\
\text { 12-Jul-06 }\end{array}$ & $\begin{array}{c}\text { Wed, } \\
\text { 19-Jul-06 }\end{array}$ \\
\hline $\begin{array}{l}\text { Westbound } \\
\text { voyage }\end{array}$ & $T X 248 W$ & $T X 250 \mathrm{~W}$ & $T X 252 \mathrm{~W}$ & $T X 254 W$ & $T X 256 \mathrm{~W}$ & $T X 258 \mathrm{~W}$ \\
\hline $\begin{array}{l}\text { Long } \\
\text { Beach }\end{array}$ & $\begin{array}{c}\text { Mon, } \\
\text { 26-Jun-06 }\end{array}$ & $\begin{array}{c}\text { Mon, } \\
\text { 03-Jul-06 }\end{array}$ & $\begin{array}{c}\text { Mon, } \\
\text { 10-Jul-06 }\end{array}$ & $\begin{array}{c}\text { Tue, } \\
\text { 18-Jul-06 }\end{array}$ & $\begin{array}{c}\text { Mon, } \\
\text { 24-Jul-06 }\end{array}$ & $\begin{array}{c}\text { Mon, } \\
\text { 31-Jul-06 }\end{array}$ \\
\hline Oakland & $\begin{array}{c}\text { Fri, } \\
\text { 30-Jun-06 }\end{array}$ & $\begin{array}{c}\text { Sat, } \\
\text { 08-Jul-06 }\end{array}$ & $\begin{array}{c}\text { Fri, } \\
\text { 14-Jul-06 }\end{array}$ & $\begin{array}{c}\text { Sat, } \\
\text { 22-Jul-06 }\end{array}$ & $\begin{array}{c}\text { Fri, } \\
\text { 28-Jul-06 }\end{array}$ & $\begin{array}{c}\text { Fri, } \\
\text { 04-Aug-06 }\end{array}$ \\
\hline Xiamen & $\begin{array}{c}\text { Sun, } \\
\text { 16-Jul-06 }\end{array}$ & $\begin{array}{c}\text { Sun, } \\
\text { 23-Jul-06 }\end{array}$ & $\begin{array}{c}\text { Sun, } \\
\text { 30-Jul-06 }\end{array}$ & $\begin{array}{c}\text { Sun, } \\
\text { 06-Aug-06 }\end{array}$ & $\begin{array}{c}\text { Sun, } \\
\text { 13-Aug-06 }\end{array}$ & $\begin{array}{c}\text { Sat, } \\
\text { 19-Aug-06 }\end{array}$ \\
\hline
\end{tabular}


Port selection criteria adopted by carriers are essential to the successful performance of the liner shipping business in terms of capacity utilisation and revenue management. Basic strategies are driven by the consideration of a number of factors (Branch, 1998; Lirn et al., 2004) such as:

- The amount of profitable cargo can be generated.

- The existence of feeder networks affecting the flexibility of the cargo trans-shipment arrangements to minimise ship turnaround time.

- To facilitate rapid cargo trans-shipment, the port authority, shippers, agents, customs, trade associations and inland transport operators should be taken into consideration.

- The berth layout and other port facilities, e.g., stacking area at container yards and container handling equipment.

- The port should operate $24 / 7$ in order to shorten vessel berthing time.

- Efficiency of port operations that can improve ship turnaround time and overall cargo transit time.

- A good intermodal network, where terminals are designed for ease of inter-modal transfer to and from road, rail and inland waterway transport.

- The port should be strategically located on a major shipping lane and supported by a strong hinterland.

- The availability of bunker and ship repair facilities in the port and their charges need to be considered.

- Modern ports are fully computerised in all areas of terminal operations. The adoption of technology is essential to turnaround time of vessels.

- Port competitiveness in terms of costs is also important. Terminal handling charges, storage charges and availability of free time at terminals are key determinants.

To serve mega-size container ships, there are constraints on ports. For instance, ports must have adequate depth of water, wide channels, long berths, high-speed cargo handling equipment, a highly productive and reasonably priced labour force, suitable berths for coastal feeder vessels and good road and rail intermodal connections to inland destinations (Ircha, 2001). Capital-intensive large container ships require a fast turnaround time. On the other hand, shippers require frequent liner shipping service to meet their just-in-time and flexible-production requirements. The liner shipping industry needs to cut costs by building larger ships, potentially creating overcapacity that depresses rates, which leads to stronger need to cut costs (Haralambides, 2000).

\section{Hypotheses development}

Managers usually perceive growth and scale operations as desirable business goals. Growth leads to economies of scale and increase in firm size is often associated with prestige and the ability to withstand dynamic business environment. Due to rising 
customer expectations for shipping services, a deeper and wider scope of service is required to satisfy the operational needs of the shippers. Shipping firms have offered comprehensive services such as increasing the number of ports of call and sailing frequency to improve their global market coverage. To broaden their service scope, many shipping firms are offering a wide range of related services such as container terminal operations and logistics related services. In the container shipping industry, the association of firm size with scale operations affects performance of firms. Firm size is therefore an important issue in business research, leading to abundant findings about firm size effects. For instance, increasing scale may lower cost (Porter, 2004). Large firms may be in a better position to spread the fixed costs over a larger production based. Large size operations provide the means for geographical expansion and facilitate global operation (Dobrev and Carroll, 2003).

A firm can be viewed as a collection of resources and an optimal pattern of firm expansion requires a balance use of its resources (Wernerfelt, 1984). In the context of container shipping, capacity can be one of the resources for high returns. Production processes with increasing returns to scale yield high returns. Economies of scale in the use of resources are one of the prime examples of product entry barriers. As a result, the increase in the carrying capacity of the biggest container shipping firms has accentuated the characteristic of concentration operations in the industry. Large firms are more likely to acquire their competitors (Palmer and Barber, 2001). For example, Hapag-Lloyd acquired CP ships forms one of the world's top five container shipping firms. The merging of Maersk and P\&O Nedlloyd, as well as of CMA CGM and Delmas, has led to consolidation on an unprecedented scale in the container shipping industry. Today, a few players can account to $50 \%$ of the container shipping market (Traffic World, 2005). It is expected that firm size affects returns on investment, therefore:

Hypothesis 1 The carrying capacity of container shipping firms is positively associated with their firm performance.

Shipping is one of the world's most capital intensive industries (Lun and Quaddus, 2009). Operating larger ships leads to substantial reductions in cost per TEU. For instance, a vessel of 12,000 TEU on the Europe-Far East route would generate an 11\% cost saving per container slot compared to a 8,000 TEU vessel and a $23 \%$ cost saving compared to a 4,000 TEU ship (Notteboom, 2004). From the resource-based view, history is an important determinant of firm performance. Performance of a shipping firm not only depends on the industry structure but also on the path a shipping firm has followed through history to arrive where it is today. The acquisition of mega ships as capital resources depend upon the historical position of a firm (Barney, 1991). A mega ship is an expensive capital investment. The return on investment of mega ships depends on the volume of trade. If investment in ships takes place but trade does not grow, then expensive ships will have to be laid-up. The shipping market is driven by a market mechanism to determine freight rate. Excessive demand leads to shortage of ships, which in turn lead to higher freight rates in the shipping market. Similarly, excessive supply of ships leads to lower freight rates. Shipping cycle can be seen as a consequence of the market mechanism. Mega ships are expensive to purchase. The costs of adding or reducing fleet size are high. Purchasing mega ships incurs significant risks as the capital cost takes many years to recover. Based on the concept 'supply rigidity' (Fusillo, 2004), shipping managers usually order new mega ships only when a definite trend in increased demand is assured. 
Cost efficiency is one of the most popular size-based strategies for shipping firms through acquisition of mega ships. An interesting question to discuss is: what is the relationship between ship size and shipping costs? Metaxas (1971) has examined how ship size affects shipping costs. His findings are summarised as follows:

- $\quad$ reduced ship construction cost per slot

- the number of crew increased slightly with an increase in ship size

- costs of lubes and stores, maintenance and repairing and administration increased as the size of a ship increased but far less than in proportion

- $\quad$ economies of scale can be gained by spreading the management and insurance costs.

Other antecedents of deploying mega ships include: large ships allow carriage of higher cargo volume per ship; large ships equipped with efficient engines leading to higher vessel speed; greater flexibility in the container stowage; better stability and lesser heeling motion in port reduce loading and unloading time (Fossey, 1994). To achieve scale economy in ship size, container shipping firms order mega ships. This is illustrated by the fact that container shipping firms increased their global fleets significantly, adding about 110 post-Panamax vessels in capacity from 5,500 TEU to 9,500 TEU in an 18-month period ending in 2006 (Mongelluzzo and Leach, 2006).

Shipping cost is a key determinant in shipping operations. Generally speaking, shipping costs involve voyage costs and vessel operating costs. Voyage costs can be defined as variable costs incurred for a particular voyage. The main items include fuel costs, port dues, service charges and canal charges (Stopford, 2004), as illustrated below:

$$
\mathrm{VC}_{\mathrm{tm}}=\mathrm{FC}_{\mathrm{tm}}+\mathrm{PS}_{\mathrm{tm}}+\mathrm{CD}_{\mathrm{tm}}
$$

where

$$
\begin{aligned}
& \mathrm{VC}=\text { voyage costs } \\
& \mathrm{FC}=\text { fuel costs } \\
& \mathrm{PS}=\text { port dues and service charges } \\
& \mathrm{CD}=\text { canal dues } \\
& \mathrm{t}=\text { year } \\
& \mathrm{m}=\mathrm{m}^{\text {th }} \text { ship. }
\end{aligned}
$$

In container shipping operations, vessel operating costs are expenses incurred through vessel operations, which are made up of five key items, including:

$$
\mathrm{OC}_{\mathrm{tm}}=\mathrm{M}_{\mathrm{tm}}+\mathrm{IN}_{\mathrm{tm}}+\mathrm{RM}_{\mathrm{tm}}+\mathrm{SL}_{\mathrm{tm}}+\mathrm{AD}_{\mathrm{tm}}
$$

where

$$
\begin{aligned}
& \mathrm{OC}=\text { operating costs } \\
& \mathrm{M}=\text { manning costs } \\
& \mathrm{IN}=\text { insurance costs } \\
& \mathrm{RM}=\text { repair and maintenance costs }
\end{aligned}
$$




$$
\begin{aligned}
& \mathrm{SL}=\text { store and lube costs } \\
& \mathrm{AD}=\text { administration costs } \\
& \mathrm{t}=\text { year } \\
& \mathrm{m}=\mathrm{m}^{\text {th }} \text { ship. }
\end{aligned}
$$

The compositions of the operating costs are made up of five key elements as: manning costs, repair and maintenance costs, insurance costs, store and lubes costs and administration costs (Ocean Shipping Consultants Ltd., 2004). Economies of scale can be achieved through spreading the administration costs, store and lubes costs and manning costs. As ship size is likely to affect firm performance, we develop the following hypothesis:

Hypothesis 2 Shipping firms that deploy larger ships achieve better performance.

The introduction of mega ships has placed additional burdens on ports terminals with the provision of direct call services instead of the hub-and-spoke approach. There are several drawbacks of using mega ships (Stopford, 2004), which include:

- Using very big ships requires deep dredging of ports and extensive feeder services to ports that may not be able to accommodate them.

- Feeder costs dwarf the savings on using bigger ships on deep sea trades.

- Feeder vessels can be highly inefficient. For instance, there is an extra set of port costs involved because containers need to be unloaded (or loaded) from the feeder vessel and transferred to the main vessel at the hub port.

The regularity and frequency of shipping service should be considered when determining the number and sizes of ships required. The emergence of complex logistics networks has led to a demand for shipping service characterised by high frequencies, high schedule reliability and low transit time. Transit time can be defined as the number of sailing days on a port-to-port basis. Transit time can also be considered the total time on a door-to-door basis, which includes dwell time at terminals and the time needed for pre-carriage at the port of loading and on-carriage from the port of discharge. A key factor affecting port-to-port transit time is the order of the ports of call on the shipping service loop. Decisions on the order of ports of call are determined by such factors as cargo volume generated at the ports, distribution of hinterland, berth availability and geographical location. On the other hand, a fast growth in cargo volume will lead to port congestion, which affects the reliability of shipping schedules. Shipping lines are constantly balancing factors such as the risk of late arrivals and the minimisation of transit time (Notteboom, 2006). Hence, the number of ships deployed also plays an important role in affecting the performance of shipping firms. Thus:

Hypothesis 3 Shipping firms that deploy more ships can achieve better performance. 


\section{Tests and results}

In this study, objective data were used to test the hypothesis. Data of total carrying capacity, number of ships and average ship size of the top 100 ocean carriers were collected from AXS-Alphaliner (http://www1.axsmarine.com/public/publicTOP100.php) in 2008. The descriptive statistics of the 100 container carrier is shown in Table 3. The carrying capacity of the 100 container carriers ranges from 5,246 TEUs to 1,964,570 TEUs with a mean of 115,045 TEUs. The number of ships operated by them is between three and 544 with a mean value of 47.14. Their average ship size is from 291.44 TEUs to $4,450.57$ TEUs with a mean value of $1,456.40$ TEUs. To evaluate the effects on firm performance, the data of ocean carriers' earning before interest and tax (EBIT) was collected from Drewry Shipping Consultant Limited to serve as performance indicators.

Table 3 Descriptive statistics of the 100 container carriers

\begin{tabular}{lcccc}
\hline & $N$ & Minimum & Maximum & Mean \\
\hline Carrying capacity (in TEUs) & 100 & 5,246 & $1,964,570$ & 115,046 \\
Number of ships & 100 & 3 & 544 & 47 \\
Average ship size (in TEUs) & 100 & 291 & 4,450 & 1,456 \\
\hline
\end{tabular}

To test the hypotheses, the technique of regression model is used and the results are shown in Table 4. In the regression models, beta coefficient $(\beta)$ measures the strength of the relationship between a dependent variable and an independent variable. Beta coefficient allows for a direct comparison between coefficients as to their relative explanatory power of the dependent variable (Hair et al., 2006). Our first hypothesis suggests that capacity of container shipping firm positively affects their firm performance. According to our test results, carrying capacity is related to firm performance (with $\beta=0.901$ at the $p=0.000$ level). Therefore, our findings lend support for Hypothesis 1. Our second hypothesis conjectures that shipping firms deploy larger ships have better performance. Our findings suggest that ship size is related to firm performance (with $\beta=0.539$ at the $p=0.008$ level). Hence, Hypothesis 2 was supported. The third hypothesis proposes that shipping firms deploying more ships can achieve better performance. Our findings indicate that number of ships deployed positively affects firm performance (with $\beta=0.874$ at the $p=0.000$ level). Thus, Hypothesis 3 was supported.

Table 4 Results of regression models

\begin{tabular}{lcccccc}
\hline Hypotheses & $\begin{array}{c}\text { Independent } \\
\text { variables }\end{array}$ & $\begin{array}{c}\text { Dependent } \\
\text { variables }\end{array}$ & $R^{2}$ & $\begin{array}{c}(\beta) \text { beta } \\
\text { coefficient }\end{array}$ & Sig. & Results \\
\hline 1 & Carrying capacity & EBIT & 0.812 & 0.901 & $0.000^{*}$ & Accept \\
2 & Average ship size & EBIT & 0.291 & 0.539 & $0.008^{*}$ & Accept \\
3 & Number of ships & EBIT & 0.765 & 0.874 & $0.000^{*}$ & Accept \\
\hline
\end{tabular}

Note: *Significant at $\mathrm{p}<0.01$ level

Our findings reveal that carrying capacity of shipping firms positively affects their firm performance. Fleet mix involves the number of ships and the size of ship deployed. To examine the causal relationship among the components of fleet mix and firm performance, we used path analysis. Path analysis is a useful statistical technique for 
examining complex empirical models. In this study, we use structural paths to examine the causal relationships among the variables and assess their strengths in influencing firm performance of container shipping firms. In a path analysis, the beta coefficient (B) measures the strength of the relationship between a dependent variable and a predictor variable. A summary of the statistical relationships among the study variables in the regression models and the regression beta coefficient $(B)$ is reported in Table 4 . The regression coefficient $(ß)$, which indicates the degree to which each predictor variable is explained by other predictor variables, is a common unit of measure in path analysis. The regression coefficient ( $($ ) provides information about the functional relationships between pairs of variables, predicting how much the dependent variable changes with a given change in any of the different causal variables. A path diagram is a visual representation of a model and the complete set of relationships among the variables in the model. The path diagram to illustrate how the factors of average ship size and number of ships affect firm performance is shown in Figure 1.

Figure 1 Structural paths affecting firm performance

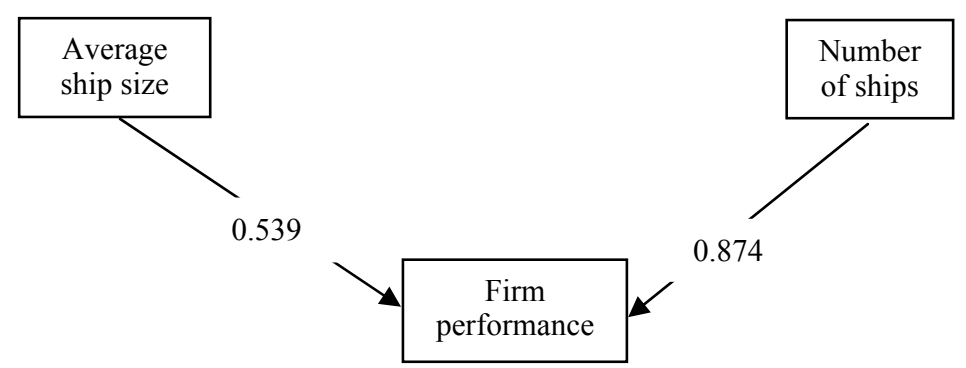

\section{Discussions and conclusions}

The results of this study, in general, supported our Hypothesis 1 that capacity of container shipping firms positively affects their firm performance. As fleet mix involves number of ships and size of ship, we used path analysis to examine the impacts of number of ships and average ship size. In our model, both average ship size and number of ships positively affects firm performance. In comparing the magnitude of the effects on firm performance, number of ships (with a $\beta=0.874$ ) is stronger than average ship size (with a $\beta=0.539$ ). Although ship size and firm performance are positively associated, our results indicate that number of ships is a key determinant that affects performance of container shipping firms.

In the shipping literature, an abundant research was devoted to large vessels and its effect on substantial reductions in cost per TEU of capacity. Carriers can be benefited from deploying mega ships when the ships are full. The results of this study suggested that a broad scope of shipping service by deploying more ships play a significant role in influencing performance of container shipping firms. When designing fleet mix, scope of shipping service is a key factor to be determined. Accordingly, we propose a 'SCOPE' framework to assist decision making for fleet mix. This 'SCOPE' framework consists of the following five elements: 
- Service frequency: It is better to offer a high service frequency which is at least a weekly service. However, there will be a trade-off between service frequency and scale operations. Smaller ships allow more frequent services which are desirable from shippers' perspective, but larger vessels allow operators to benefit from economies of vessel size. Fleet mix decision is not only a function of carrier-specific operations factors but must also cater for shippers' needs for service frequency, reliability and other service elements.

- Customer value: In the last two decades, carriers have reshaped the liner shipping network through the use of new types of end-to-end services particularly on the high-volume international trade routes. These types of pendulum service focus on hub-and-spoke system which allows carriers to deploy large ships to reduce cost. To create customer value, liner shipping services tend to change from a cost-driven operation to a more customer-oriented approach.

- Optimal vessel size: The optimal vessel size depends on cargo availability, transit time and service frequency. From the carriers' point of view, efficient shipping systems are the lowest cost operations via hubs and deploy largest ships. However, shippers could avoid these services due to poor service frequency, low accessibility and long transit time. When deploying large ships, carriers need to search for cargoes to fill the ships and be aware of port restrictions. With the lack of flexibility in offering shipping services, it can be a potential burden in a shrinking market.

- Ports of call: Limiting the number of port calls will shorten the voyage time and increase the number of round trips per year. With fewer ports of call, the number of vessels deployed for a specific service can be reduced. Nevertheless, fewer ports of call mean poorer access to cargo catchment areas. More ports of call can generate more cargoes which can be additional revenue to carriers. A cost-efficient liner shipping service from carriers' perspective could be an inconvenient service from the shippers' perspective in terms of flexibility and transit time.

- Extensive market coverage: Delivering superior service values and strengthening ongoing relationships with shippers are important goals for carriers. It is essential for shipping firms to have a timely response to evolving market changes. In essence, a liner shipping firm can be self-sustained under one of two conditions:

1 attaining the firm size that would serve a specified range of international trade routes

2 targeting regional markets.

Because of the need to provide extensive market coverage to fill the ever-growing capacities of ships, many carriers have responded by pooling their resources together to establish a network. By doing so, they are able to extend market coverage and enter markets that cannot be served adequately by operating alone, driving firms to pursue network-based organisations.

The implications of this study are two-fold, which can be drawn from the perspectives of both researchers and managers. From a research perspective, our empirically tested fleet mix model identifies the factors that affect performance of container shipping firms. Our findings suggest that carrying capacity is a key factor that influences firm performance in the container shipping industry. Firm performance is also affected by number of ships 
and average ship size. Our findings imply that the number of ships is a relatively important determinant of fleet mix than carrying capacity in influencing firm performance. From a management perspective, our findings indicate that there are a number of factors affecting firm performance such as carrying capacity, number of ships and average ship size. According to our path analysis as shown in Figure 1, number of ships has the greater impact on firm performance when comparing to average ship size. Our results explain the important roles of service scope in the liner shipping industry. This study also proposes a 'SCOPE' framework, consists of five elements, i.e., service frequency, customer value, optimal vessel size, ports of call and extensive market coverage, to examine the fleet mix in liner shipping services.

The limitations of this study can be viewed in term of methodology. Methodologically, the data collected for this study were based on secondary sources. A disadvantage of using secondary data is that the user has no control over the accuracy and reliability of the data. Moreover, this study was limited to the area of container shipping. For future research, the study can be extended to the other shipping market such as bulk shipping. A comparison between the container shipping market and the bulk shipping market will be useful in understanding the determinants of fleet mix of different market segments in the shipping industry.

\section{Acknowledgements}

This study was supported in part by The Hong Kong Polytechnic University under grant number J-BB77.

\section{References}

Barney, J. (1991) 'Firm resources and sustained competitive advantage', Journal of Management, Vol. 17, No. 1, pp.99-120.

Branch, A.E. (1998) Maritime Economics, Stanley Thornes.

Cullinane, K. and Khanna, M. (2000) 'Economies of scale in large containerships: optimal size and geographical implications', Journal of Transport Geography, Vol. 8, pp.181-195.

Dobrev, S.D. and Carroll, G.R. (2003) 'Size (and competition) among organization: modeling scale-based selection among automobile producers in four major countries, 1885-1981', Strategic Management Journal, Vol. 25, pp.541-558.

Fleming, K.D. (2002) 'Reflections on the history of US cargo liner services, part I', Maritime Economics and Logistics, Vol. 4, pp.369-389.

Fleming, K.D. (2003) 'Reflections on the history of US cargo liner services, part II', Maritime Economics and Logistics, Vol. 5, pp.70-89.

Fossey, J. (1994) 'Post-panamax breakthrough', Containerization International, September, p.47.

Fusillo, M. (2004) 'Is liner shipping supply fixed?', Maritime Economics and Logistics, Vol. 6, pp. 220-235.

Gilman, S. (1999) 'The size economies and network efficiency of large containership', International Journal of Maritime Economics, Vol. 1, pp.5-18.

Hair, J., Black, W., Babin, B., Anderson, R. and Tatham, R. (2006) Multivariate Data Analysis, Pearson Education International, New Jersey.

Haralambides, H.E. (2000) 'A second scenario on the future of the hub-and-spoke system in liner shipping', Latin Port and Shipping 2000 Conference \& Exhibition, Miami, FL, USA. 
Ircha, M. (2001) 'Serving tomorrow's mega-size containerships: the Canadian solution', International Journal of Maritime Economics, Vol. 3, pp.318-332.

Kwan, C. and Knutsen, K. (2006) 'Intermodal revolution', China Business Review, Vol. 33, No. 4, pp.20-25.

Lirn, T.C., Thanopoulou, H., Beynon, M.J. and Beresford, A. (2004) 'An application of AHP on transhipment port selection: a global perspective', Maritime Economics and Logistics, Vol. 6, pp.70-91.

Lun, Y.H.V. and Quaddus, M.A. (2009) 'An empirical model of the bulk shipping market', International Journal of Shipping and Transport Logistics, Vol. 1, No. 1, pp.37-54.

Lun, Y.H.V., Lai, K.H. and Cheng, T.C.E. (2009) 'Intermodal transport capability', Shipping and Transport Logistics Book Series, Vol. 1, pp.17-33.

Metaxas, B.N. (1971) The Economics of Tramp Shipping, The Athlone Press of the University of London.

Midoro, R. and Pitto, A. (2000) 'A critical evaluation of strategic alliances in liner shipping', Maritime Policy and Management, Vol. 27, No. 1, pp.31-40.

Mongelluzzo, B. and Leach, P.T. (2006) 'Flexibility', Journal of Commerce, 9 January, Vol. 1, available at ABI/INFORM Global database - Document ID: 959576041.

Notteboom, T. (2004) 'Container shipping and ports: an overview', Review of Network Economics, Vol. 3, No. 2, pp.86-106.

Notteboom, T. (2006) 'The time factor in liner shipping services', Maritime Economics and Logistics, Vol. 8, pp.19-39.

Ocean Shipping Consultants Ltd. (2004) Shipping Profitability to 2015 - The Outlook for Vessel Costs and Revenue, Ocean Shipping Consultants Ltd., Surrey, UK.

Palmer, D. and Barber, B.M. (2001) 'Challengers, elites and owning families: a social class theory of corporate acquisitions in the 1960s', Administrative Science Quarterly, Vol. 46, pp.87-120.

Porter, M.E. (2004) Competitive Advantage, Free Press, New York.

Robinson, R. (1998) 'Asian hub/feeder nets: the dynamics of restructuring', Maritime Policy and Management, Vol. 25, pp.21-40.

Robinson, R. (2002) 'Ports are elements in value-driven chain systems: the new paradigm', Maritime Policy and Management, Vol. 29, No. 3, pp.241-255.

Rodrigue, J.P. and Comtois, C. (1997) 'Transportation and spatial cycles: evidence from maritime systems', Journal of Transport Geography, Vol. 5, No. 2, pp.87-98.

Slack, B., Comtois, C. and McCalla, R. (2002) 'Strategic alliances in the container shipping industry: a global perspective', Maritime Policy Management, Vol. 29, No. 1, pp.65-76.

Song, D.P., Zhang, J., Carter, J., Field, T., Marshall, J., Polak, J., Schumacher, K., Proshum, S.R. and Wood, J. (2005) 'On cost-efficiency of the global container shipping network', Maritime Policy and Management, Vol. 32, No. 1, pp.15-30.

Song, D.W. (2003) 'Port co-opetition in concept and practice', Maritime Policy and Management, Vol. 30, No. 1, pp.29-44.

Stopford, M. (2004) Maritime Economics, Routledge.

Ting, S.C. and Tzeng, G.H. (2004) 'An optimal containership slot allocation for liner shipping revenue management', Maritime Policy and Management, Vol. 31, No. 3, pp.199-211.

Traffic World (2005) 'Bigger ships, bigger lines', Traffic World, Vol. 19, p.1.

UNCTAD (2004) Review of Maritime Transport, United Nations.

Wernerfelt, B. (1984) 'A resource-based view of the firm', Strategic Management Journal, Vol. 5, No. 2, pp.171-180. 